\title{
Lone Friis Thing
}

\section{Er emotioner som vilde galoperende heste?}

En mikrosociologisk anvendelse af Norbert Elias' emotionsbegreb med elitesport som eksempel

Ved hjælp af emotionsbegrebet tolkes den symbolske leg med aggression i elitesport som et interaktionsritual for iscenesættelse af tabubelagte emotioner og kropspraktikker.

Artiklen forsøger, med udgangspunkt i den nyere emotionssociologi, at præcisere styrker og svagheder ved den figurationsteoretiske sportsanalyse. 
S ociologen T.D. Kemper pointerer, at emotioner har været anset som noget qvasi-videnskabeligt. Alligevel fremhæver han, at emotioner ofte smugles ind i sociologien under kategoriseringer og begrebsliggørelser så som attituder, karisma og socialklasseidentitet (1990:3). Den kritiske emotionssociolog Randall Collins, som også har udvist interesse for emotionsbegrebet og emotioners betydning for den sociale orden, magt og status (1975), fremhæver, at emotioner er del af de sociale interaktioner og dermed et område, som også vedrører sociologien (1990). G. Bendelow og S. Williams (1998) skriver ligeledes, at emotioner har været et område, som den klassiske sociologi berørte implicit, dog uden at referere det eksplicit. Marx' fremmedgørelses begreb, Durkheims forståelse af moralsk solidaritet og Simmels beskrivelser af bylivets stemninger fremhæver Bendelow og Williams som områder, hvor emotioner indgår i sociologien (1998:131). Fokuseringen på emotioner kan derfor ikke karakteriseres som værende en ny disciplin i sociologien, selvom emotionssociologien for alvor først voksede frem fra midten af 1970'erne (Bloch 1994). Trods det at emotioner sjældent tematiseres i det sociologiske landskab og måske endda ligesom kroppen kan beskrives ved deres fraværende tilstedeværelse (Shilling 1995), har flere sociologer fremhævet, at emotionsbegrebet lever, men lever på skyggesiden.

Det er ikke ofte, at Norbert Elias' metodologi, figurationssociologien, fremhæves når emotioner problematiseres. Det er bemærkelsesværdigt, fordi Elias inkluderede emotionsbegrebet i sin modernitetsanalyse. Norbert Elias skrev Civilisationsprocessen i 1939, hvor emotioner og krop er de grundlæggende analyseenheder; men 50 år senere blev disse altafgørende begrebsmæssige omdrejningspunkter i hans analyser af moderne fri- tidsliv og sport (Elias og Dunning 1986).

Nærværende artikel vil problematisere emotioners betydning og funktion i den vestlige moderne elitesport. Artiklen er en afgrænset mikrosociologisk analyse af emotionsbegrebet i den figurationelle sociologi. Med udgangspunkt i empiriske fortællinger om aggression i holdsport $\mathrm{t}^{1}$ kritiserer jeg begrebsliggørelsen og sprogliggørelsen af emotioner i den eliasianske tradition. Jeg benytter empiriske udsagn om aggression og spændingssøgning inde på selve banen til at sige noget om, hvad aggression (og emotioner) handler om i sport. De empiriske udsagn benyttes til at argumentere for en vending eller overskridelse i figurationsteoriens emotionsforståelse. Jeg forsøger at følge den selvkritiske begrebsvending, som den britiske sociolog Joseph Magui$\mathrm{re}^{2}$ har skitseret til traditionen, men som han ikke har arbejdet empirisk med.

Ved at præcisere og uddybe emotionsforståelsen i Norbert Elias' og Eric Dunnings sportsteori fremhæves både styrker og svagheder ved deres teori. Kritikken er anvendelsesorienteret og loyal, omend mit bidrag består i at påpege at emotionsbegrebet, og måden der skrives om følelser på i sportsteksterne, er uklare og kræver formuleringer, der er tidssvarende rent emotionssociologisk. Artiklen er afgrænset til emotioner, og jeg vil derfor ikke forsøge at inddrage mere omfattende figurationsteoretiske elementer, så som forholdet mellem individ og fællesskab, spiller-holdrelationer, medspillermodspillerrelationer, publikum, medier eller sport-samfundsrelationer ${ }^{3}$. Disse elementer vil kun indgå i den grad, de er relevante for den specifikke emotionsteoretiske diskussion.

Aggression i sport relateres til sportens samfundsmæssige funktion og til sportens symbolske orden og vil her udelukkende blive fremhævet som et emotionsteoretisk eksempel. Denne afgræns- 
ning medfører ikke at sport i det moderne samfund udelukkende handler om aggression. Sport er fx også emotionelle glædesmanifestationer og et socialt rum for synliggørelsen af stolthed, skam og spænding. Sport er ligesåvel fællesskabsdannende, identitetsskabende og dermed et udtryk for nationalstaters positionering (Maguire 1999)4. Sport er derved en samfundsmæssig institution, der potentielt indeholder positive fællesskabsdannende dimensioner, men som ligeledes kan være ophav til konflikter mellem konkurrerende grupper, sociale klasser, køn og etniske grupper (Hoberman 1984). Disse følelsesområder og temaer er ikke omdrejningspunkter for denne korte artikel.

\section{Aggression i elitesport}

For Norbert Elias og Eric Dunning 5 er begreber som vold (violence), aggression (aggression) og spænding (excitement) vigtige omdrejningspunkter i sportsudøvelsen (Elias \& Dunning 1986). Aggression stammer sprogligt fra ag-gredior, fra: ad gradior. Her betyder ad: 'til' eller 'hen imod' og gradior: 'tage skridt' eller 'gå'6. Aggression hentyder derfor sprogligt oprindeligt til det at gå frem mod.

Der findes over 200 teoretiske definitioner af aggression (Berliner, Karpatschof \& Kuschel 1991). Hverken i de psykologiske, de antropologiske eller de sociologiske teoriretninger har man været i stand til at fuldføre endegyldige og klart forståelige definitioner af fænomenet. I stedet for den enkle og korte definition af aggression samler interessen i forskningen sig ofte om at forsøge at kategorisere aggression i flere forskellige typologier.

Eric Fromm beskrev i The Anatomy of Human Destructiveness det, han betegnede som den menneskelige legesyge aggression (Fromm 1973:255). Fromm foretog dermed en analytisk distinktion mellem det symbolsk aggressive og det ondskabs-

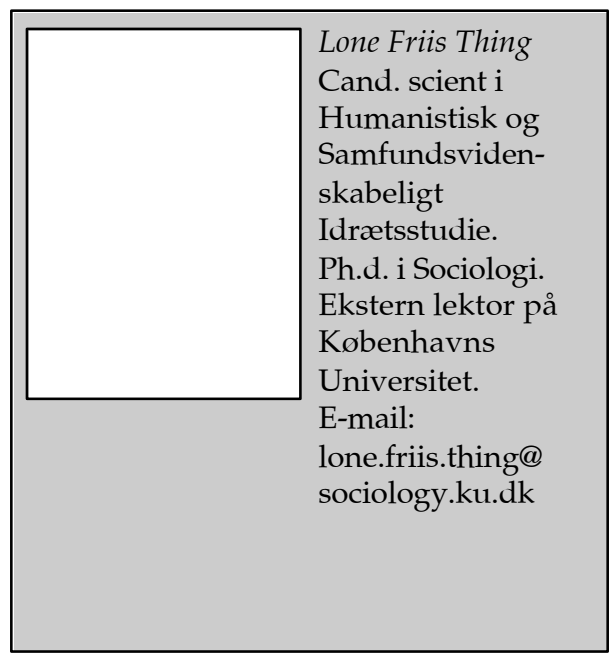

fuldt aggressive - volden. Den legesyge aggression har som sit fornemmeste formål at udfolde og efterstræbe the exercise of skill, det som vi kunne benævne som udfoldelsen og perfektioneringen af den kropslige kompetence. Denne aggressionsform udfoldes ikke for at skade og harme medmennesket og adskiller sig derved fra den instrumentelle aggression (Dunning 1983). Den legesyge aggression er ikke motiveret af hadet eller uvenskabet, men er tværtimod en kunstart og en stræben efter den perfekte kropslige bevægelse og den perfekte kropslige kompetence. Fromm nævner som et eksempel den zenbuddhistiske sværdkamp, men han henfører også vores moderne sport til den legende aggression. Konkurrencesport er figurationsteoretisk set indbegrebet af kamp mellem mennesker (Elias \& Dunning 1986). Kunst og sport adskilles ved at fremhæve, at sport har karakter af kamp og har en lighed med 'reelle' kampe mellem rivaliserende samfundsgrupper. Den lystprægede søgen efter kamp udfoldes i sporten på en symbolsk, legende facon, men i en regelfast kontekst, som producerer spænding, lyst og aggression (Maguire 1992). Det er den legesyge aggression, som har været fokus for undersøgelsen. 


\section{Sportens samfundsmæssighed}

Elias beskriver den vestlige verdens samfundsudvikling som en sammenhængende proces mellem to aspekter, som på den ene side er statsmagtens centralisering og på den anden adfærdskodernes forandring. I Civilisationsprocessen ${ }^{7}$ fremgår det, hvorledes kropsligheden og emotionaliteten langsomt er blevet disciplineret og tabubelagt op gennem historien. Elias tegner et billede af forandringerne i de sociale forskrifter vedrørende væremåder, smag og handling. Tesen er, at der er udviklet en gradvis forfinelse af kontrollen af de sociale standarder, således at menneskets evne til at udøve selvbeherskelse er blevet forøget (Elias 1982). Hovedvægten i Elias' arbejde er lagt på idéen om, at der fra det 14. århundrede er sket en gennemgribende adfærdsbegrænsning og regulering af voldshændelser i samfundet bredt set. Med fremkomsten af det moderne samfunds statsorganisering er tesen, at staten har monopol på kontrollen af de aggressive emotioner gennem institutioner som militær, politi og retsvæsen. Elias mente, at forbudet mod fysisk vold gav en større stabilitet $\mathrm{i}$ samfundet, men han påpegede, at det måske betød et tab af lystfyldte former for spændingsoplevelser og et tab af en tilfredsstillelse i forbindelse med mere affektive og spontane adfærdsformer.

Individets frie muligheder for udfoldelse af aggression bliver ifølge Elias og hans kollega Dunning i moderniteten henvist til sportens verden. Sport analyseres som en betydningsfuld sfære for spændingsfyldte emotionsoplevelser og som muligheden for at udtrykke emotionelle og kropsligt voldsomme sider af tilværelsen. Figurationsteoretisk anskues sport derfor som en samfundsmæssig institution for skabelse, men også som afladning af spænding og aggression. Sport har en rutinenedbrydende effekt, er en modbevægelse og en mulighed for at løs- ne den emotionskontrol, som Elias og Dunning ser udfoldet i det sociale liv mere generelt (Elias \& Dunning 1986:120). Tesen er, at civilisationsprocessen har bevirket en forfinelse af forholdet til fysisk aggression, hvilket igen skaber et socialt behov for at bearbejde aggressive kropslige impulser, og her træder sporten ifølge den eliasianske tradition ind som en driftsmæssig aflastningsstruktur.

\section{Elias' driftsperspektiv}

Elias og Dunning beskriver emotionsprocesserne i sport ved den magiske nøglesætning om en"kontrolleret afkontrollering" af emotioner (ibid 1986:96). Loyalt kan denne sætning tolkes som muligheden for følelsesmæssig tilfredsstillelse, da sport løsner den allestedsnærværende selvkontrol, og følelserne derved mister deres bidende brod. Sætningen signalerer, at "afkontrolleringen" sker under kontrollerede forhold. Sportens ramme og særegne logik, dommerhvervet og sportsetikken (fairplay og gentlemanprincippet) sørger med andre ord for, at udfoldelsen af krop og følelser ikke løber løbsk.

Men det kritiske perspektiv øjner det freudianske efterslæb i Elias' tænkning. En tænkning, som jeg ikke mener emotionssociologisk er tilstrækkelig. For hvad menes der egentlig med termen en "kontrolleret afkontrollering"? Det modsætningsfyldte i ordvalget, ambivalensen og tvetydigheden mellem kontrol og af-kontrol mener jeg tydeliggør uklarheden i begrebsliggørelsen. Af-kontrollering henviser til, at selvkontrollen slippes, og at individets beherskelsesmekanismer sættes fri, for en kortvarig stund. Her ligger et naturargument og lurer. For at afkontrollering overhovedet kan komme på tale, må der være en underliggende naturlighed, en essens, en ægte elementær biologisk drivkraft, som kan gives friløb og stemme. 
Elias fremhævede kroppens og følelsernes formning. Han så krop og følelser som tids- og kulturbundne. Han beskrev, hvorledes den psykodynamiske struktur $\mathrm{i}$ individet er afhængig af de samfundsmæssige lag. Men selvom Elias ikke definerer emotioner som latente egenskaber, der sidder inde i kroppen, og selvom Elias ikke troede på dødsinstinktet og selvaggressiviteten (Elias 1986:157) som naturlige kernebestanddele og akulturelle størrelser, og trods det at Elias ønskede at analysere instinkter som del af organismens helhed, så fortæller ordvalget: "den kontrollerede afkontrol" alligevel, at Elias falder tilbage på den freudianske civilisationskritik. Elias skriver:

The de-controlling function of leisure activities which opens up the way for the refreshment of emotions is on its part too surrounded with precautionary rules so that it can be socially tolerable (Elias \& Dunning 1986:115).

Og andetsteds:

It is highly characteristic of civilized man that he is denied by socially instilled self-control from spontaneously touching what he desires, loves, or hate (Elias 1994: 166).

Citaterne viser, at rationaliteten er effektivt installeret i kødet. Kontrol og overvågning af seksualitet, aggression og vold præger det moderne liv. Det er civilisationen, der sikrer mådehold og social orden. Begrebsliggørelsen antyder, at civilisering og disciplinering er ødelæggende kræfter, der kræver sit frikvarter. I det sociale må der være behov for et frisættelsesrum, en kroppens legeplads.

Der refereres ikke direkte til det freudianske driftsperspektiv hos Elias og
Dunning, men grundlaget er tydeligt. Ord som spændingsbalance, spændingskontrol og selvkontrol kan alle knyttes an til det freudianske og instinktmæssige, emotionsteoretiske grundlag, og tanken om at forstå emotioner som impulser, der skal aflades, er gennemgående. Flere steder i Quest for excitement sammenlignes sportsudøvelsens katharsis med den spændingsafladning, som finder sted ved den seksuelle akt (Elias \& Dunning 1986:58).

De meningsmæssige forståelser og ritualer, der kunne ligge i det mimetiske, som rækker ud over en spændingsskabelse og en spændingsafladning af emotionsenergi, bliver ikke beskrevet uddybende hos Elias og Dunning. Et andet moment, der eksemplificerer driftsgrundlaget er ordet "outburst", som går igen flere steder i sportsteksterne. "Outburst' betyder på dansk at springe ud, bryde frem eller revne og henviser til en form for indre drift, der holdes i ave (ibid 71). Ord som frisættelse, klimaks og "arousal" blomstrer ligeledes mange steder $\mathrm{i}$ teksterne. Begrebsliggørelsen "kontrolleret afkontrollering" er historien om, at den eksterne kontrol (den ydre begrænsning) opretholdes af sportens regelsæt, men at den indre kontrol (selvkontrollen) løsnes.

Det uklare i formuleringen er, at Elias på den ene side fremhæver, at emotioner er formet i kulturen, men på den anden side, specielt i sportsteksterne, vælger at nedtone mødet med kulturen og i stedet uddyber de somatiske og fysiologiske forløsningspotentialer i sport (ibid 88).

\section{Hvad er emotioner?}

Den amerikanske sociolog Arlie Hochschild opdeler overordnet emotionssociologien i to områder (1983). Den ene tradition benævner Hochschild som den organismiske model, repræsenteret af $\mathrm{fx}$ Darwin og Freud, hvor emotionernes be- 
tydning reduceres til en biologisk proces af instinktmæssig karakter, som pga. instinktets natur altid finder sin libidinøse udløsning. Den anden model, og modsætningen til den første, benævner Hochschild som den interaktionistiske model, repræsenteret eksempelvis af den fortolkende emotionssociologiske tradition, og med udspring bl.a. i sociologen Erving Goffmans arbejder.

I den interaktionistiske tradition er tyngdepunktet samlet om interessen at analysere emotioner som sociale og kulturelle mekanismer. Det interaktionistiske perspektiv har øje for den mindste enhed i det sociale bånd, dimensionerne skam og stolthed (Scheff 1990), agtelsessystemet om værdighed og forlegenhed (Goffman 1974 (1959); 1967), og fokus på de sociale forskrifter, som vejleder og koordinerer emotionerne (Hochschild 1983; 1998). Til disse to emotionssociologiske traditioner kan man tilføje mindst to mere. Denfigurationelle tradition repræsenteret emotionssociologisk ved eksempelvis Wouters (1998) og Burkitt (1991; 1997), samt den konstruktivistiske tradition som udfoldes af bl.a. Gergen (1997) og Harré (1986). Som det vil fremgå af det følgende, har alle traditionerne både ligheder og forskelle og er derfor svære at modstille på en enkel måde.

Maguire skaber et begrebsskift i den figurationsteoretiske emotionsforståelse og påpeger, at den interaktionistiske tradition på konstruktiv vis kan supplere Elias' og Dunnings sportsteori. Begrebsskiftet medfører, at Maguire teoretisk set bevæger sig væk fra Elias' og Dunnings begrebsliggørelse af "lystfuld spænding" (pleasurable excitement) i sport, som er en freudiansk emotionsforståelse, der primært anskuer emotioner som driftstyrede. Maguire introducerer "spændingsbetydning" (exciting significance) som et nyt begreb.

Begrebsskiftet betyder at, emotioner defineres som både kropslige affekter og sproglige dimensioner. Der lægges relativt mere vægt på rituelle elementer og sprog end på driftafladning i forhold til, hvad Elias og Dunning gjorde. Dette giver mulighed for at fortolke sport mere kreativt (om man vil) og mere nuanceret med hensyn til sportens funktion og symbolske indhold. Begrebsskiftet åbner også for det prekære kulturrelativistiske spørgsmål: Om sport er det samme i forskellige kontekster.

Dette begrebsskift afviger egentlig ikke fra Elias' overordnede definition af emotioner, skrevet i tekster, der ikke handler om sport. Elias fremhævede emotionssyndromet som indeholdende tre aspekter: En adfærdskomponent, en fysiologisk komponent og en følelseskomponent (Elias 1991:116). Følelseskomponenten fortæller præcist, at menneskets evne til at verbalisere emotionstilstande er afhængig af sprog og læring (ibid 118). Det strider derfor ikke mod Elias' definition af emotioner at pointere betydningen af sprog og kultur i forhold til følelsesvokabulariet, trods det at Elias og Dunning vægtede emotionernes "frie forløb" i deres sportsanalyse (Elias \& Dunning 1986: 58).

Elias ønskede selv at nedbryde myten om, at emotioner var såkaldte naturlige dispositioner (Elias 1991). På den anden side pointerede han også, at socialvidenskaberne skulle være varsomme med at distancere sig fra det kropslige, fra biologien og den fylogenetiske udviklingsproces. I artiklen "On Human Beings and their Emotions" (Elias 1991) forsøger Elias at overkomme natur/kultur-forholdet som en modsætning. Ifølge Elias kan hverken det sociale liv eller emotioner reduceres til et biologisk spørgsmål, som den organismiske tradition har for vane at gøre. Men det er ifølge Elias ikke en løsningsmodel blot at skelne mellem den biologiske udvikling på den 
ene side og den socio-kulturelle udvikling på den anden. Elias beskriver natur-kultur forholdet som et hængsel (ibid 114). Natur og kultur er gensidigt afhængige størrelser i menneskets udviklingsproces og kan som sådan ikke adskilles.

Den emotionsteoretiske vending fra "lystfuld spænding" til "spændingsbetydning" (Maguire 1999) ser jeg som en anledning til at nytænke emotionsforståelsen i den figurationelle tænkning. Det er her, jeg ser muligheden for at indoptage emotionsteoretiske betragtninger fra den mikrosociologiske interaktionistiske tradition. Jeg bevæger blikket og definitionen af emotioner fra en" indre", iboende mekanisme (et driftsforhold) til et socialt forhold, der udspringer af mødet mellem mennesker.

\section{Emotioner er mere end affekt}

Kritikken af driftsperspektivet (det organismiske) skal ikke ses som et ønske om at bortradere eventuelle eksisterende drifter, men gives for at fremhæve, at betydningen og funktionen af de emotionelle møder i sport er komplekse. Elias ønskede i sin emotionssociologi en dialektik mellem drifter og kontrollen af drifterne (Elias 1982). Han påpegede, som før nævnt, vigtigheden af dialektikken mellem naturgrundlaget og kulturgrundlaget, og hans idé var at se forholdet som et funktionelt kontinuum (ibid 287). Drifterne og kontrollen deraf kan ikke anskues som isolerede enheder, men må i stedet ses som relaterede, netop fordi de er udviklet og formet gennem langstrakte historiske og sociale processer.

Det er derfor vigtigt at fastslå, at vi ikke forskningsmæssigt må overse springet fra dyr til menneske. Men vi kan heller ikke adskille det biologiske grundlag og det menneskelige sociale fundament, idet de altid og allerede er indvævede $\mathrm{i}$ hinanden. Den menneskelige refleksive virksomhed, vores forestillingsevne og sunde fornuft gør, at vi allerede som nyfødte indlejres i kulturen, sproget og den sociale omverden, og det pga. vores mulige evner for læring. Denne udkastethed i verden, denne socialisering og "overgang" er med Elias' egne ord hængslet.

\section{Bidraget fra den symbolsk interaktionistiske tradition}

Erving Goffman har analyseret hverdagslivets sociale interaktioner med et ritualperspektiv inspireret af den durkheimske tænkning (Goffman 1967). I den mikrosociologiske, interaktionistiske tradition repræsenteres det rituelle i den sociale interaktion og ikke udelukkende i forhold til det magiske eller overnaturlige. Det hellige beskriver Goffman som selvets facade, ansigtet, som individet viser udadtil i den sociale omverden. I de kommunikative hverdagsinteraktioner beherskes den sociale dans, så de involverede parter ikke "taber ansigt" og mister selvrespekt. Ifølge Goffman opretholdes og vedligeholdes ansigtsfacaden på en sådan måde, at selvet og personligheden ikke lider et æretab, således at personen kan forlade den sociale interaktion på en respektfuld facon.

Arlie Hochschild tager et lignende udgangspunkt i forhold til emotionsbegrebet. Hochschild integrerer den interaktionistiske og organismiske freudianske tradition for ikke helt at glemme kroppens affektfunktion (1998). Hendes position er, at selvet og kroppen via det emotionelle har et redskab til at forstå sin omverden. Her indplacerer hun netop ikke kroppen og det affektive som primært og førstkommende i forhold til den kulturelle og sociale interaktion, som instinktivisterne gør det. Hun ser den emotionelle reaktion som selvets fornemmelse af, hvor det "står" i den sociale omverden (Hochschild 1983:31). Hochschild definerer emotioner som en kropslig orientering til en imaginær handlingssituation. 
Emotioner er en signalfunktion, som gør os opmærksomme på, hvor vi står, både set i forhold til selvets "ydre" (omgivelserne) og "indre" situation (det personlige). Det emotionelle bliver derved et ofte nonverbalt, kropsligt og kommunikativt bindeled, som forbinder os med vores objektive omverden.

Hochschild repræsenterer her det emotionsteoretiske perspektiv, der lægger fokuseringen på det sociale og kulturelle som determinerende for emotionerne. Det viser sig, at mennesket tillægger emotioner forskellige betydninger og forholder sig forskelligt til emotioner alt afhængigt af de kulturelle og sociale forskrifter. Man kan udtrykke det sådan, at der i forskellige sociale og kulturelle landskaber deles en kollektivt defineret emotionel "ordbog", som ved hjælp af kontekstuelle, normative emotionsregler guider os i vores måder at håndtere, bearbejde og fortolke emotioner på (Hochschild 1998). Dette betyder, at vi i den sociale realitet konfronteres med forventninger og krav til, hvordan vi skal manøvrere det emotionelle. Nærmere bestemt ved vi (både bevidst og ubevidst) i kraft af vores opvækst, hvad vi bør gøre og ikke bør gøre. Vi er bekendte med fællesskabets forventninger og konsekvensen er, at vi udfører emotionsarbejde i tilpasningen til omverden (Hochschild 1983).

Opsummerende og fælles for de to traditioner, den figurationelle tradition og den interaktionistiske, er derfor, at de ved hjælp af emotionsbegrebet forsøger at overkomme spørgsmålet om hængslet, forholdet mellem natur og kultur. Begge traditioner tager emotioner som udgangspunkt for analyser af de sociale relationer og mener, at emotionssociologi kan perspektivere karakteren af de sociale bånd og dermed også give information om, eller være indikatorer for fællesskabet og den sociale orden. Forskellen er dog, at det freudianske grundlag hos interaktionisterne ikke dominerer analytisk.

\section{Den symbolske kamp: ansigt til ansigt}

Jeg vil nu præsentere nogle af de aggressions- og kropspraktikker, som elitekvinder i boldspillene fodbold, ishockey og basketball udtrykker på selve banen i den kropsnære konkurrence- og kampsituation $^{8}$. De symbolske og rituelle elementer, der ligger i "det aggressive møde“ $\mathrm{i}$ sport, uddybes for at vise, at aggression $i$ elitesport er mere end afkontrollering af drifter. Empirien er derfor en anvendelse af den skitserede begrebsvending i figurationsteorien. Aggressionsfortællingerne skal sandsynliggøre, at emotioner også kontrolleres i sport. Empirien viser, hvorledes regler følges, og hvordan spillerne vejledes til at følge sportskulturens skik og brug. Men læseren vil også få et indblik i, hvordan kvindespillere udfolder nogle emotionskvaliteter, som de siger, de ikke har mulighed for at udfolde $\mathrm{i}$ andre samfundsmæssige institutioner ${ }^{9}$. Det bemærkelsesværdige ved de empiriske udsagn om aggression inde på selve banen er fortællingernes manglende antydning af driftstyring.

I den interaktionsproces, der udfolder sig mellem de involverede hold på sportsarenaen og mellem de involverede personer på banen, udspilles der en kamp ansigt til ansigt, som både mentalt, kropsligt og emotionelt handler om at udfordre og nedbryde facaden. Rollespillet om "den aggressive ansigtsfacade" beskrives på følgende måde:

Der er to former for aggressivitet. Der er den, man retter mod sit eget hold i en ren frustration over, at spillet bare overhovedet ikke fungerer. Og så er der den aggression, man retter mod sin modstander, hvor man egentlig hele tiden har 
en eller anden kamp kørende. Lad os begynde med den mest positive, som trods alt er den, der er rettet mod modstanderne. Der er jeg tit utrolig aggressiv. Det er hele tiden en udfordring, at man spiller over for en spiller, og der er kamp. Kan jeg slå dig, eller kan du slå mig? Hvis man ikke hele tiden har den der aggressivitet i sig og lysten til at vise, at det sgu' er mig, der er bedst af os to, så kommer man ikke nogen vegne.

(...)

Når du står i spilsituationer og har en spiller foran dig, så er det eneste mål du har, det er, at jeg skal være bedre end hende. Jeg skal vise, at jeg er bedre end hende, helt sikkert. Det kan godt være, at det er aggressivitet, for mig er det lige så meget et spørgsmål om det at have en eller anden vilje til at ta' kampen op og hele tiden at skulle bevise over for sig selv, men også over for omverdenen, det ved jeg, det har jeg utrolig meget brug for. Det er at bevise, at jeg kan sgu' godt. Prøve mine egne grænser af og se hvor langt jeg kan gå, og hvor langt kan jeg tage den her konkurrence op med en spiller, som er bedre end mig. Hvor langt kan jeg egentlig strække det?

Den positive aggressionstilstand er den orientering, som spilleren har i forhold til modspilleren. I kampsituationen er man konstant orienteret mod det at udfordre og overgå den modspiller, som man konfronteres med. Spilleren ser tilstanden som positiv og som en bestandig del af hendes konkurrence om målet at vinde kampen. Håndteringen af den "lille" kamp (modstander mod modstander) i den "store" kamp (hold mod hold) skal sættes i relation til det overordnede mål at vinde og at konkurrere. Den aggressive relation til modspilleren er en del af rollespillet, som styrer spillerne i ansigt til ansigt-situationen:

Man er aggressiv, man er virkelig aggressiv, også når en spiller på ens hold har gjort et eller andet fuldstændig latterligt, så kan man få en lidt stram bisse på. Men så siger man undskyld bagefter. Når man er inde på banen, så ved man godt, at man er hidsig, og man sveder, og der er en kamp. Så det er ikke rigtig noget, man tænker over.

Det aggressive er en attitude og en fastholdelse af orientering i konkurrencesituationen. Den negative aggressionsproces er den frustration spilleren oplever, når hendes eget hold ikke længere formår at spille optimalt. Spillerne reflekterer også over begrebet og sætter det i relation til konteksten uden for sporten. Der er aggression knyttet an til vold, hvilket aggression ikke er inde på banen. Da jeg forsøger at få Anna til at uddybe forskellen mellem den legende aggression og volden, forklarer hun:

Nå, men der er, i hvert fald inden for basket og i alle sportsgrene nogle regler for, hvad man må og ikke må. De voldelige tendenser, de er jo næsten altid pillet ud. I basketball er de udfoldelsesmuligheder ret afgrænsede, du kan ikke være voldelig. Men du kan godt være utrolig aggressiv og være inden for grænserne. Fordi at du bruger din krop, og du er krop mod krop, men ikke sådan at du skader din modspiller. Det er meget "rent", kropskontakt, at du må bruge hele din ryg mod hendes krop. Men du må ikke bruge din arm i skub. Så det er....er en mere 
stor fladekontakt, når der er kontakt, lovlig kontakt, og det kan være enormt aggressivt og enormt hårdt, men der er ikke stor chance for, at der er nogen, der kommer til skade.

Undersøgelsen viste, at en eskalering fra den symbolsk aggressive leg til vold stadigvæk sker relativt sjældent i den ikke kommercielle danske kvindesport.

Ishockeyspilleren Lene siger om kropsfornemmelsen i det spilaggressive således:

Det er som om, at musklerne, hver eneste muskel i ens krop, er spændt. Man er simpelthen opmærksom på sådan hver lille detalje, som modspilleren laver. Og så får man simpelthen ekstra kræfter, man kan simpelthen køre derudaf. Fordi man har det mål, altså man sætter sig det mål, at enten skal der ikke gå mål ind hos os, eller at: „Hun skal i hvert fald ikke runde mig“. Sådan forskellige mål kan man sætte sig, store og små. Sådan er det hele tiden. Men overordnet har jeg jo et mål om, at jeg skal vinde, og der skal ikke gå mål ind.

De aggressive processer er for de interviewede kvindespillere en del af spillet på banen, som udfoldes per automatik: Med en kropslig "tavs viden".

Man kan sige, at aggressionsudtrykket er en praktik installeret som en disposition, der spontant kommer til udtryk, men udtrykket er forårsaget af den kulturelle og sociale øvelse. Udfordringen handler om at konfrontere sig med interaktionen, med modspilleren og nedbryde "den andens" facade. En spiller fortalte, hvorledes hun mistede sin kontrol:
Det var på et tidspunkt, hvor jeg spillede en landskamp. Hvor jeg spillede mod en tysk pige, der stod og holdt i mine shorts, så jeg ikke kunne flytte mig. Hun stod så tæt på mig, så dommeren ikke kunne se det, og jeg blev simpelthen bare så målløs, så jeg hidsede mig op tilsidst. Altså, I kender det godt, når man ikke kan trække vejret, man bliver hidsig. Jeg kunne slet ikke gøre noget ved det, jeg blev overrasket.

Som beretningen vidner om, er det uhensigtsmæssigt at miste kontrollen. Spilleren fortæller historien, fordi den siger noget om, hvad aggression ikke er på banen. Spilaggression er den kontrollerede emotionalitet, ikke tabet af kontrol. En naturlig afkontrollering ville spillerne derfor ikke komme langt med.

Maskeradens mening er at opnå, vedligeholde og fastholde positionen som overlegen spiller. Interaktionsprocessen i kampsituationen på banen kan derfor analyseres som en kontrast til de interaktionsprocesser, som sædvanligvis udfoldes i hverdagslivet. Spillet er en aftalt iscenesættelse, en koordineret asocial omgangsform. Istedet for at udvise respekt for "den andens" integritet, kæmpes der på boldbanen om det at komme bag ved facaden. Derfor er interaktionsritualet på boldbanen et episodisk brud med de hverdagslige praktikker og sociale forventninger, som kvinderne kender fra deres daglige liv. Angrebs- og forsvarskampen i grænselandet handler om at besidde og indtage rummet både verbalt og kropsligt, emotionelt og mentalt.

\section{Det lystfyldte i den legende aggression}

Aggression må forstås i forhold til sportens logik, særegne regelsæt og normativitet. Når aggression italesættes i andre 
livssfærer, er aggression sædvanligvis ikke forbundet med følelser af glæde og stolthed eller indlejret i forhold til et fastlagt regelsæt, som vi finder det i sporten. Ishockeyspilleren fortæller, hvordan hun oplever kampen som både positiv, udfordrende og sjov:

Første gang da hun prøvede at løbe ind mod mål, da var den eneste måde jeg kunne stoppe hende på, det var ved at løbe ind i hende....frontalt ind i hende. Fordi hun....hvis man prøver at slå med stokken eller et eller andet, så løber hun jo uden om én. Der var det mig, der var den, der faldt. Men hun kom ikke forbi, og hun scorede ikke. Jeg fik bidt mig i læben, så det blødte. Det er sådan, det er. Det er godt. Senere hen i kampen, der smed jeg mig i et af hendes slagskud, så jeg knap nok kunne komme op at stå igen.

Interviewer: Ramte pucken dig?

Ja, hun skød den lige ind over mit knæ. Hun skød ret hårdt (griner). Det er sådan noget, der bliver man, så er man "tændt" og sådan. Det er dét, der er sjovt. Det er udfordringen i det.

Beskrivelsen viser glæden ved og lysten til den hårde og kontante kropslige kamp, som spilleren oplever, når hun udfører sine opdækningsopgaver for holdet. Boldspilleren oplever det som både sjovt og udfordrende, når spillet holdes inden for rammerne af regelsættet. Man kan derfor ikke konkludere, at aggression er lig med vold, og man kan heller ikke konkludere, at emotioner som aggression og glæde nødvendigvis udelukker hinanden.

I sprogliggørelse af sammenhængen mellem aggression, glæde og lyst ser jeg træk og betydninger, som viser, at kvinderne $i$ undersøgelsen udfolder en levende, kropslig leg med håndteringen af emotioner. Linda, som har været ishockeyspiller i snart en del år, men som tidligere var kunstskøjteløber, forklarer den forskel, som hun har erfaret mellem kunstskøjteløb og ishockey:

Den glæde man har ved at betragte spillet, når man er ude at spille. At vide, at man kan se, bare den lille ting jeg gør for holdet. Det...hvis du laver et flot opspil, så kan der gå to pas, så er pucken i hovedet på mig igen. Det er måske glæden ved at se, du skaber det, det er jo ikke som i kunstskøjteløb. I skøjteløb, der er et program, altså, du ved, hvad du skal, så er ishockeyspillet ligesom uforudsigeligt. Det er også det, der gør det spændende....det går så stærkt, så du er nødt til at have en forhåndsidé med det du vil lave. Men alligevel så kan det gå galt. Der kan lige pludselig komme én, som du ikke har set. Så kan hele spillet vende igen. Så skal du tænke hurtigt igen, tænke konstruktivt. Hvordan er denne situation bedst? Hvordan kan jeg nu hurtigt vende spillet igen? Altså det handler om at være rolig, kold, det er bare spænding.

Citatet viser, at den omtalte spænding ikke udelukkende er noget fysisk, en forløsende somatisk tilstand som skitseret af Elias og Dunning.

Legen med spænding og spilaggression iscenesættes nemlig også i selve træningssessionerne, træning efter træning, år efter år. Til træningen øver spillerne forskellige rollespil. Spillerne øver sig i håndteringen af emotioner, de øver sig 
på at være barske, konfronterende og snu. Der trænes ligeledes på ikke at gå i fælden, når taktikken udfoldes mod én selv. Spillerne træner derfor på iscenesættelsen af aggressivitet. Både på at frembringe den rette spilaggressive kropsattitude og på at forme emotionsudtrykket i kropsbilledet. Når spillerne udviser glæde, når de smiler og sejrsivrigt triumferer ved scoringer, straffekast og udvisninger, er handlingerne ikke spontane reaktioner, men ofte et udtryk for seriøst indarbejdet kropsmanagement. Den kropslige positionering er magtspillets omdrejningspunkt og har stor betydning for holdets indsats, som ovenstående citat vidner om.

Emotionaliteten (her aggressiviteten) iscenesættes verbalt: Eksempelvis med nedgørende bemærkninger, kølig ironi eller brændvarme opråb. Men emotionaliteten udtrykkes også non-verbalt med kropslige tegn. Det er kropsligt indøvede måder at udfordre modspilleren på, som elegant indgyder til respekt.

Kampe og aggressive konflikter kan derfor udstråle afkontrollering og ureflekteret handling, men er tværtimod strategisk og velovervejet:

\begin{abstract}
Altså, hvis jeg nu tirrer hende lidt og slår hende lidt bag på haserne. Bag på skinnebenet. Og står og slår hende lidt dér, mens dommeren ikke kan se det. Og tager staven op bagved bukserne og generer lidt. Eller mellem benene, eller sådan et eller andet. Så til sidst, så synes hun ikke det er skægt mere, og så vender hun sig om og slår mig.
\end{abstract}

I interviewene med spillerne over de observerede konflikter gav spillerne udtryk for en forbavselse over mine tolkninger. Et fald, eller en ophidset tone, viste sig ofte at være skuespil. Dette betyder ikke, at der ikke udfoldes reelle voldshandlinger i sport, men undersøgelsen viser, at spilaggression generelt kan siges at være en kontrolleret aktivitet. Helheden i den sociale figuration må medtænkes, hvis aggressionen skal gøres forståelig.

\section{Det sportslige emotionsarbejde}

Hochschild benytter sig af begrebet følelsesregler til at forklare de forskrifter, der guider emotionelle udtryk i forskellige kulturer. Følelsesregler er normative standarder, som anvendes for at bedømme, hvilken emotionsreaktion der er passende i den pågældende kultur (Hochschild 1983). Skiftet mellem den sportslige rolle og selvet træner kvinderne at kunne håndtere. De tillærer sig følelsesreglerne:

Ja, det er noget med at give slip på sig selv, at give slip på sin hverdag. Når jeg spiller, ja, men jeg er jo ikke anderledes, og alligevel, hvordan skal man sige det....Det er jo stadigvæk mig, der spiller, ikke også, men en anden side af mig.

En anden spiller udtaler:

Det er ligesom om, at vi når vi kommer bag alt det udstyr, vi har på, så er vi et hold, altså vi er ens på en eller anden måde, som vi ikke er uden for banen. Pigen, som måske er en, er en lille stille pige, bliver måske en eller anden vild, og det er bare. Når man så har badet, eller når man går ud og er færdig, så er man sig selv igen. Så er det ligesom....Man skjuler måske sig selv...ja, eller måske viser man mere sig selv, som man ikke tør gøre, gøre i dagligdagen på en eller anden måde. Fordi det er acceptabelt, at man råber eller gør en eller anden svinestreg. Hvis der på gaden kommer èn eller anden gå- 
ende, nede på gågaden, og skubber til én, så har man vildt lyst til at skubbe igen, det er ikke acceptabelt, vel. Det kan man gøre på isen, på en eller anden måde.

Det at være "personlig" på boldbanen henviser til at involvere sig med en modspiller, så koncentrationen flyttes væk fra holdet og det overordnede spil. Spilleren distanceres fra fællesskabsfølelsen og holdet 'Os' i en personligt involveret fornærmethed over en hændelse eller en verbal chikanering og fanges ind af sit personlige tankegods. Det at være personligt involveret er et brud med de uskrevne regler, de følelsesregler, som findes i kulturen. Spillerne har erfaringer med, at den personlige involvering kan resultere $i$, at den legesyge aggression eskalerer til vold, og at det personlige ødelægger holdfællesskabet.

Kvinderne øver sig under træning og i kampene på at undgå konfliktsituationerne og på at lære at håndtere emotionsprocesserne. Emotionsarbejdet med at opretholde facaden i en given institutionel sammenhæng foregår både på et overflade- og et dybdeniveau (Hochschild 1983). Overflade- og dybdearbejde af emotionsreaktioner er en orienteringspol, som genfindes i sport. Hvis selvet bliver berørt af rollespillet, som udfoldes på overfladen, må selvet udføre et dybdearbejde for at kunne fastholde rollespillet. Jo mere erfaren en spiller er, desto bedre giver spillerne indtryk af at være i stand til at håndtere "glidebanen" mellem spilrollen (den ydre attitude) og selvet (den indre fornemmelse).

Spilaggression og rollespillets dybde får fylde ved hjælp af forskellige teknikker, som holdet indøver kollektivt for at opnå den rette stemning. Ishockeykvinderne samles rituelt i en lille cirkel foran målet før kampens begyndelse. Taktfast slår de stavene ned i isen, således at en hul lyd gennemtrænger hallen. Ritualet skaber en kollektiv bevidsthed og er med til at sætte rammen for det mentale skift og individets indtræden i kampens større helhed.

Kampen for holdet, spillernes involvering og aktive indsats evalueres af spillerne selv umiddelbart efter kampens afslutning. Kvindefodboldholdet havde et kæledyr, som efter hver kamp blev overrakt til den bedst spillende spiller. På demokratisk vis valgte spillerne i omklædningen, ved simpel anonym afstemning, ugens kvinde. Det spilaggressive element er derfor ikke enkelt en indre psykologisk tilstand, men kan mere beskrives som en strategi, der må forstås relationelt og tolkes i forhold til holdet og sportens overordnede logik.

Således har Elias ret i, at den emotionalitet, der udfoldes i sport, står i skærende kontrast til livet uden for sport. Men en enkel afkontrollering af kontrol genfindes ikke i citaterne fra de interviewede. Interviewene viser et episodisk brud med den normativitet, vi kender fra hverdagslivet, men fremtræder dog alligevel regelbundet og koordineret. Sporten aktualiserer en emotionel tilstedeværelse, men den fremtræder sportsligt kultiveret. Emotionsarbejdet består i at skjule det personlige. Spillerne overvåger hinanden, de har fingeren på pulsen, og det mindste tab af selvkontrol hos modspilleren udnyttes eller straffes fordelagtigt.

Maskespillet handler om at modstå provokationer. I basketball kan provokationerne $\mathrm{fx}$ være de forbudte urene småslag med armene. I ishockey kan det være slag med staven, som rammer steder på kroppen, hvor beskyttelsesudstyret ikke dækker. Og i fodbold ses ofte tacklinger bagfra, som foregår, når 1. dommeren er optaget andetsteds. Novisen klarer ikke disse magtspil om det aggressive. Den øvede og erfarne spiller reagerer kontrolleret og behersket og følger spillets 
uskrevne reglen.

Når spilleren bliver personlig (træder ud af spilrollen), er der en risiko for at tabe ansigt (og dermed miste selvrespekt og ære). Det at involvere sig personligt er kort og godt utilfredsstillende for holdet og for fællesskabet. Kampen og rivaliseringen handler om, hvem der er i stand til at fastholde facaden og rollen længst, mest magtfuldt. Man involverer ikke unødigt sit personlige selv. Meningen med det symbolsk aggressive spil kan derfor siges at være netop $i k k e$ at lade de personlige aggressioner få frit løb. Det essentielle omdrejningspunkt er spillet om kontrollen og iscenesættelsen af facaden.

\section{Konklusion}

Hvor Elias (og Dunning) fastholder, at de følelsesmæssige bindinger bliver løsnet eller befriet for det sociale pres i sport, så fremhæver jeg en emotionskontrol også i sport. Der er med andre ord også forskrifter, regler og normer, som guider emotionerne i sport. Så svaret på artiklens overskrift, om emotioner er som vilde galoperende heste, er nej. Jeg ønsker således at radikalisere Elias' tænkning. Sportsaktivitet kan ikke udelukkende ses som modsætningen til hverdagsliv, men må ses som en processuel, uafsluttet socialisering og beherskelse, om man vil.

Det tager flere år at lære den kropslige og mentale kultur, og det kræver nogle gange blod, sved og tårer at holde kulturen ud i sport. Sport er med andre ord ikke stedet, hvor spillerne smider masken og er "personlige". Der arbejdes hårdt for ikke at være "personlig", og der kæmpes ligeledes hårdt for at opnå status og for at indgå i magtspillet.

Reglementet i sport binder spillerne til at lære og til at acceptere grænser for handling. Det er ikke alt, der er tilladeligt i sport. Som etableret, magtfuld spiller er man loyal over for kulturen og helliger sig emotions- og kropspraktikkerne.
Man udfordrer grænselandet mellem det legende aggressive og volden og forsøger hele tiden at være på forkant, at overskue situationen til holdets bedste. Empirien viser, at det er en profan handling at træde ud af spilrollen for at fremhæve sin "personlige" interesse og integritet. Udfoldelsen af kamp og symbolsk aggressiv konfrontation i mødet ansigt til ansigt, krop mod krop, er handlinger, som kræver mod og moralsk overvejelse. Spilhandlinger i elitesport bevirker en bearbejdelse af moralske dilemmaer og berører tabuer i vores kultur. Meningen i det symbolsk aggressive karakteriserer jeg som en iscenesættelse af selve det asociale. Sportsrammen løsriver individet fra hverdagslivet, fordi rammen indskriver anderledes regler og en anderledes moral end hverdagslivets. Jeg mener derfor, at Dunning er på afveje, når han fastholder, at emotioner i sport ikke styres af forskrifter, når emotioners funktion i sport primært beskrives ved deres organismiske træk (Dunning 1999:3).

Elitespilleren er i kampen underlagt holdmentaliteten og det overordnede mål at vinde. Det er ikke kulturelt ideelt at udfolde sig frit og individuelt følelsesmæssigt. Der er social status i at fastholde maskeraden. Man efterstræber at holde sig fra de mere selviske målsætninger.

Aggression begrebsliggøres flertydigt i sportskonteksten alt afhængigt af funktionen af det aggressive og aggressionsprocessens betydning for fællesskabet. Karakteristisk er det, at aggression i forhold til modspilleren tegnes som en positiv dimension, men hvis den eskalerer til „det, der meningsmæssigt rækker ud over spilkonteksten", og hvis den får en personlig orientering, beskrives handlingerne som vold, og volden beskrives $i k k e$ som sport - den forsøges undgået. Det er derfor vigtigt at påpege, at relationens karakter har afgørende betydning for 
navngivningen og forståelsen af det aggressive i sport. Det er relationens karakter og konteksten, der gør aggressionen forståelig.

Artiklen introducerer en emotionssociologi, som ikke analyserer emotioner som affekter. Emotioner kan fortolkes og tilskrives mening, idet emotionaliteten er historisk, kulturel, social og normativt bundet. Emotionaliteten er ikke en fri og uafhængig størrelse. Vi kan blive klogere på vores samfund ved at reflektere over de kulturelle og kollektive udtryk, som emotionerne har, og ved at belyse de sociale strukturers begrænsninger og mulighedsskabende betydninger for det emotionelle. Derfor er emotioner også en konstruktion. En konstruktion, som har bund i samfundsmæssigheden, men som inkorporerer kroppen og dens biologi. Så trods det at emotioner i artiklen på sin vis defineres som en social konstruktion, er der ikke tale om en konstruktivistisk tænkning.

Det figurationsteoretiske og det interaktionistiske synspunkt befinder sig på en mellemvej, som kan karakteriseres som en tredje løsningsmodel til det metodologiske spørgsmål vedrørende debatten om konstruktivismens grænser (Järvinen 1996). Mellemvejen skitserer dobbeltheden i den menneskelige væren ${ }^{10}$. Emotionsbegrebet kan derfor være et empirisk udgangspunkt i sociologien - det kan supplere værdibegrebet - i samfundsanalyser af mikrosociologisk karakter.

\section{Noter}

1. Det empiriske materiale er hentet fra kvindesport, men jeg afgrænser mig i denne artikel fra at diskutere de kønsteoretiske aspekter.

2. Joseph Maguire er professor i sportssociologi ved Loughborough Universitet i England. Han er for tiden præsident for den sportssociologiske afdeling ISSA, under ISA. Maguire er tidligere elev af Eric Dunning fra Leicester Universitet i England og kan derfor karakteriseres som efterkommer af den eliasianske, sportssociologiske tradition. Jeg vil her benytte anledningen til at takke Maguire for hjælp og dialog om begrebsliggørelsen af emotioner hos Norbert Elias.

3. Jeg henviser her til min ph.d.-afhandling Sport en emotionel affxre. Kvinder, holdsport og aggression. Sociologisk Institut, Københavns Universitet. Og til min kollega Mads Linds ph.d.-afhandling Relationsformer i professionel fodbold. En mikrosociologisk analyse med fokus på spillernes indbyrdes relationer $i$ professionel fodbold, ligeledes Sociologisk Institut, Københavns Universitet. De to afhandlinger er udført i et samarbejde og kan ses som supplerende hinanden.

4. For sportsbegrebets mangfoldige definitioner se: Guttmann (1978), Hargreaves (1986;1994). Artiklen tager udgangspunkt i dansk elitesport for kvinder, henholdsvis fodbold, basketball og ishockey (det er ikke hensigten med denne tekst at generalisere undersøgelsens resultater til eksempelvis breddeidræt).

5. Elias' sportssociologiske arbejder er opstået i et samarbejde med Eric Dunning, der var elev hos Elias ved universitetet i Leicester, hvor Elias var ansat fra 1954-61. Dunning er i dag Emeritus Professor i sociologi ved Leicester.

6. Kilde: A Latin Dictionary, Oxford University Press, London 1975.

7. Jeg afstår fra, at gå ind i kritikken af Elias' tese om civilisationsprocessen (jfv. Eichberg 1992). Teorien om civilisationens udviklingsproces benyttes her konstruktivt for at forstå fænomenet moderne elitesport.

8. Det empiriske baseres på observationsstudier og 26 kvalitative interviews med kvinder i de danske elitedivisioner. Interviewene er foretaget $i$ et fænomenologisk perspektiv og har fokus på aggressionsfortællinger i elitesport.

9. De mestringspotentialer, der eventuelt kunne ligge i en leg med spilaggression, vil jeg ikke forfølge her.

10. Dobbeltheden i den menneskelige væren er konstruktionen af kroppen og kroppen som erfaring (Nielsen 1997). En pointe, der lægger sig tæt op af kultursociologen Søren Damkjærs kritik af socialkonstruktivismen (1998:46). 


\section{Litteratur}

Bendelow, G. \& S.J. Williams (Eds.) 1998: Emotions in Social Life. Critical Themes and Contemporary Issues. London: Routledge.

Berliner, P., B. Karpatschof \& R. Kuschel 1991: Vrede, Konflikt, Kultur. København: Dansk Psykologisk Forlag.

Bloch, C. 1994: Skam, stolthed og sociale bånd - Thomas Scheffs bidrag til følelsernes sociologi. Dansk Sociologi. Nr. 4/5. årg. - København.

Burkitt, I. 1991: Social Selves. Theories of the Social Formation of Personality. London: Sage Publications.

Burkitt, I. 1997: Social Relationships and Emotions. Sociology. Vol. 31. Nr. 1. 3755.

Collins, R. 1975: Conflict Sociology - toward an Explanatory Science. Academic Press, Inc: NY.

Collins, R. 1990: Stratification, Emotional Energy, and the Transient Emotions. I Kemper (Ed.) 1990.

Damkjær, S. 1998: Kroppens sociologi og den biologiske organisme. I Dansk Sociologi. Nr.4/9. årg. København.

Denzin, N.K. 1984: On Understanding Emotion. San Francisco: Jossey-Bass Publishers.

Dunning, E. 1983: i Goldstein, J.H. (Ed.) Sports Violence. NY: Springer-Verlag.

Dunning, E. \& C. Rojek (Eds.) 1992: Sport and Leisure in the Civilizing Process. Critique and Counter-Critique. Toronto: University of Toronto Press.

Dunning, E.G., J.A. Maguire \& R.E:. Pearton 1993: The Sports Process a Comparative and Developmental Approach. Champaign: Human Kinetics Publishers.

Dunning, E. 1999: Sport matters. Sociological studies of sport, violence and civilization. London: Routledge.

Eichberg, H. 1992: Kropsfundamentalisme? I Idrætshistorisk Årbog 8. Årg. Odense: Odense Universitet Forlag.
Elias, N. 1982 [1939]: The Civilizing Process. State Formation and Civilization. Oxford: Basil Blackwell.

Elias, N. \& E. Dunning 1986: Quest for Excitement. Sport and Leisure in the Civilizing Process. Oxford: Basil Blackwell.

Elias, N. 1991: On Human Beings and Their Emotions: A Process-Sociological Essay: I M. Featherstone, M. Hepworth \& B. S. Turner (Eds.). The Body. London: Sage.

Elias, N. 1994 [1939]a: The Civilizing Process. The History of Manners and State Formation and Civilization. Oxford: Blackwell.

Fromm, E. 1973: The Anatomy of Human Destructiveness. New York: Penquin Books.

Gergen, K. 1997: Virkelighed og relationer. København: Dansk psykologisk forlag.

Goffman, E. 1974(1959): Vårt Rollespil til dagligt. Oslo: Dreyers Forlag.

Goffman, E. 1967: Interaction Ritual. New York: Pantheon Books.

Guttmann, A. 1978: From Ritual to Record. The Nature of Modern Sports. New York: Columbia University Press.

Hargreaves, J. 1994: Sporting females, critical issues in the history and sociology of Women's Sport. London: Routledge.

Hargreaves, John 1986: Sport, Power and Culture. Cambridge: Polity Press.

Harré, R. 1986: The Social Construction of Emotions. Oxford: Basil Blackwell.

Hoberman, J. 1984: Sport and Political Ideo$\log y$. University of Texas Press: Austin.

Hochschild, A.R. 1983: The Managed Heart: The Commercialization of Human Feeling. Berkeley: University of California Press.

Hochschild, A.R. 1998: The sociology of emotions as a way of seeing. I: Bendelow, G. \& Williams, S.J. (Eds.). Emotions in Social Life. Critical Themes and Contemporary Issues. London: Rout- 
ledge.

Järvinen, M. 1996: Kön som text - om den sociale konstruktivismens gränser. Kvinder, Køn \& Forskning. Nr. 2.

Kemper, T.D. (Ed.) 1990: Research Agendas in the Sociology of Emotions. New York: State University of New York Press.

Maguire, J. 1992: Towards a Sociological Theory of Sport and the Emotions: A Process-Sociological Perspective. I: Dunning \& Rojek. (Eds.) Sport and Leisure in the Civilizing Process.

Maguire, J. 1999: Global Sport. Identities, Societies, Civilizations. Oxford: Polity Press.

Nielsen, N.K. 1997: Krop og kulturanalyser. Den levede og den konstruerede krop.
Odense: Odense Universitetsforlag. Scheff, T.J. 1990: Microsociology: Discourse, Emotion, and Social Structure. Chicago: The University of Chicago Press.

Scheff, T.J. 1994: Bloddy Revenge: Emotions, Nationalism, and War. San Francisco: Westview Press.

Shilling, C. 1993: The Body in Social Theo$r y$. London: Sage.

Wouters, C. 1998: Changes in the 'lust balance' of sex and love since the sexual revolution. I: Bendelow, G. \& Williams, S.J. (Eds.). Emotions in Social Life. Critical Themes and Contemporary Issues. London: Routledge. 